\title{
Infectivity and Inoculum Production of Phytophthora ramorum on Roots of Eastern United States Oak Species
}

T. L. Widmer, N. Shishkoff, and S. C. Dodge, Foreign Disease and Weed Science Research Unit, United States Department of Agriculture-Agricultural Research Service, Fort Detrick, MD 21702

\begin{abstract}
Widmer, T. L., Shishkoff, N., and Dodge, S. C. 2012. Infectivity and inoculum production of Phytophthora ramorum on roots of Eastern United States oak species. Plant Dis. 96:1675-1682.

Little is known about colonization of roots of trees by Phytophthora ramorum. We examined zoospore concentration and exposure time needed to infect six Quercus (oak) species and the inoculum produced from their roots. Sprouted acorns, exposed to zoospores $(3,000 / \mathrm{ml})$ for different times and transplanted to potting soil, were susceptible to infection within $1 \mathrm{~h}$ of exposure but root weights were not impacted after 4 weeks $(P=0.952)$. Roots of Quercus prinus seedlings, inoculated with sporangia, had 0.6 to $3.2 \%$ colonization of the total root mass after 5 months. Neither root lesions nor obvious root sloughing were observed. Inoculum threshold levels were tested by exposing

radicles to varying zoospore concentrations for $24 \mathrm{~h}$. Results showed that radicle infection occurred even at 1 zoospore $/ \mathrm{ml}$. To test inoculum production, roots were inoculated with sporangia and transplanted into pots. Periodically, samples of runoff were collected and plated on selective medium. Afterward, root segments were plated to calculate percent colonization. After 16 and 35 days, root colonization and inoculum production from oak was lower than that of Viburnum tinus, a positive control. This study shows that $P$. ramorum is able to infect sprouted oak acorns and produce secondary inoculum, which may be important epidemiologically.
\end{abstract}

Phytophthora ramorum Werres, de Cock \& Man in't Veld, causal agent of sudden oak death and ramorum blight, is a pathogen of worldwide concern. P. ramorum is known to have a broad host range based upon isolations from natural and artificial laboratory infections (57). In the United States, where it is a regulated quarantine organism, $P$. ramorum has a limited distribution in forests in coastal California and Oregon. To date, on the east coast, $P$. ramorum has only been isolated from nursery sites (and, in a few instances, from residential sites where infected nursery stock had been planted) and from adjacent bodies of water $(10,24)$. However, there are many susceptible forest hosts, making the potential for spread to forested areas high. If host range is taken into consideration along with other environmental factors, risk to the Eastern U.S. forests may be higher than for the Western United States $(28,29)$.

Oak species are an important part of many forests around the world, especially in the Eastern United States. The area of the two upland oak groups, oak-hickory and oak-pine, cover $43 \%$ of eastern timberland (35). Therefore, it could be devastating to natural forests if $P$. ramorum were to establish in the Eastern United States. Spaulding and Rieske (48) predicted that a nearly $38 \%$ decrease in red oak basal area would occur within 10 years of $P$. ramorum invasion in southern Appalachia. A previous study showed that, under artificial conditions, stem and leaf lesions formed on native eastern Quercus spp., including Quercus prinus L., $Q$. alba L., and $Q$. rubra L., after inoculation with $P$. ramorum (56). However, no previous studies have been conducted to look at the colonization of roots of Quercus spp. Root infection is an important infection court of many Phytophthora diseases (17), and may be very important in the life cycle of $P$. ramorum. Indeed, $P$. ramorum has a soil phase that has been demonstrated to infect the

Corresponding author: T. L.Widmer, E-mail: tim.widmer@ars.usda.gov

Accepted for publication 8 June 2012.

http://dx.doi.org/10.1094/PDIS-12-11-1024-RE

This article is in the public domain and not copyrightable. It may be freely reprinted with customary crediting of the source. The American Phytopathological Society, 2012. root systems of hosts such as tanoak, Lithocarpus densiflorus (Hook. \& Arn.) Rehd. (38,39,43,45-47,53).

$P$. ramorum has been considered primarily a pathogen that infects aboveground tissues (leaves, woody shoots, and trunks) of the host (58), with a demonstrated soil phase consisting of infected organic debris, infected roots, and persistent chlamydospores $(19,39,43)$. This ecology of the habitat of $P$. ramorum is not unusual for Phytophthora spp. A good comparable example is $P$. megakarya, causal agent of black pod disease of cacao. This species is similarly classified as an aboveground pathogen (13) but has been found on roots in low numbers (37), present in the soil as a reservoir of inoculum (21). For many years, researchers concentrated on aerial plant-to-plant spread; however, it became clear that roots became infected and that rain splash of soilborne inoculum could initiate aboveground infections $(3,36)$. Other examples that have been cited are $P$. palmivora (20) and P. cactorum (32). Davidson et al. (15) and Fichtner et al. (18) both demonstrated splash dispersal as a transmission pathway of $P$. ramorum from infested soil to aerial plant parts.

Demonstrating that $P$. ramorum has a soil phase is important epidemiologically because of the potential for movement after rain and in waterways. P. ramorum has been found in waterways, such as streams and rivers $(14,49)$, and was recovered at a forested and riparian site $1 \mathrm{~km}$ downstream of an infested site that was connected via an ephemeral stream (15). In general, $P$. ramorum has not been considered a serious root pathogen that infects via waterways, in contrast to other species such as P. lateralis (26). However, Shishkoff (47) has shown that $P$. ramorum produces inoculum levels from host roots similar to those of other documented root rot Phytophthora spp. such as P. citricola and P. citrophthora. Therefore, it is worth considering that a viable pathway for infection might occur when infested water comes in direct contact with roots.

Sporulation on different hosts is important to study in terms of the host's epidemiological impact on the spread of this pathogen. Various studies have shown that different plant species or cultivars react differently to $P$. ramorum infection in terms of necrosis and sporulation $(31,54)$. However, it is not possible to categorize a plant as conducive to sporulation and, therefore, epidemiologically important based upon the amount of necrotic tissue. Tooley and Browning (55) examined the sporulation of $P$. ramorum on several 
species but found no correlation between leaf necrosis and sporulation density. Shishkoff (46) detected $P$. ramorum propagules in runoff from various host roots, suggesting that they could serve as sources of inoculum. As such, the focus of our research was to determine whether P. ramorum is able to infect roots of Quercus spp. native to the eastern United States, and the potential of their roots to serve as a source of inoculum for infection of other hosts. Preliminary results have previously been reported $(60,61)$.

\section{Materials and Methods}

Isolates used. All work was conducted in containment at the United States Department of Agriculture-Agricultural Research Service, Foreign Disease and Weed Research Unit facility in Fort Detrick, MD under the Animal and Plant Health Inspection Service permit for $P$. ramorum. Isolates WSDA-1772 and NS-5C were originally recovered from Viburnum L. 'Mariessii' in Oregon in 2003 and Camellia sasanqua Thunb. 'Bonanza' in California in 2003, respectively. Both isolates belong to the same lineage, NA1, typically found in California and Oregon forests and U.S. nurseries $(22,30)$. These isolates have been demonstrated previously to infect a wide array of plants $(42,44,46,59)$. Furthermore, NS-5C was comparable in inoculum run-off to three other isolates of $P$. ramorum (two NA1 and one EU1), which were inoculated to Viburnum roots (47). The isolates were maintained in sterile water culture or on a Phytophthora spp.-selective medium (PARPH) containing, per liter, $10 \mathrm{mg}$ of pimaricin (Delvocid salt), $250 \mathrm{mg}$ of ampicillin, $10 \mathrm{mg}$ of rifampicin, $100 \mathrm{mg}$ of pentachloronitrobenzene, and $25 \mathrm{mg}$ of hymexazole $(34,52)$. To maintain pathogenicity, isolates were inoculated to and recovered from Rhododendron or Camellia spp. every 6 months. The isolates are also maintained in liquid nitrogen as part of the international collection of plant pathogens at the National Cancer Institute's Central Repository in Frederick, MD.

Plant species. Acorns of $Q$. alba, $Q$. prinus, $Q$. michauxii Nutt., $Q$. rubra, $Q$. palustris Muenchh., and $Q$. coccinia Muenchh. were collected in fall 2008 and 2009 in a forest in Maryland. Acorns of the white oak $(Q$. alba, $Q$. prinus, and $Q$. michauxii) were used immediately, whereas red oak acorns $(Q$. rubra, Q. palustris, and Q. coccinia) required a cold period of $4{ }^{\circ} \mathrm{C}$ for 4 months before germination. The acorns were sprouted in Fafard 52 mix (Conrad Fafard Inc.), which consists of pine bark (60\%), sphagnum peat, perlite, and vermiculite.

Infection timing. WSDA-1772 zoospores were prepared and counted by the method described by Widmer (59). Five 4-mm plugs of the isolate were added to $60-\mathrm{mm}$ plates containing sterile $20 \%$ V8 broth. The cultures were allowed to grow for 3 days at $20^{\circ} \mathrm{C}$ in the dark. The mycelium was rinsed three times in sterile $0.1 \mathrm{mM}$ 2-(N-morpholino])ethanesulfonic acid (MES) buffer, $\mathrm{pH}$ 6.2 , and then placed back in the $20^{\circ} \mathrm{C}$ incubator in the dark overnight. Zoospores were induced to release from sporangia by placing the cultures at $4{ }^{\circ} \mathrm{C}$ for $30 \mathrm{~min}$ and incubating at room temperature. After 30 to $45 \mathrm{~min}$, zoospore concentrations were determined by diluting the suspension in MES buffer, vortexing to induce encystment, and then counting on a hemacytometer. The concentration of zoospores was adjusted to $3,000 / \mathrm{ml}$ by carefully pipetting the required amount into $50 \mathrm{ml}$ of $0.1 \mathrm{mM}$ MES buffer, pH 6.2. Zoospore motility was verified by examining the suspension after dilution, using a dissecting microscope.

Due to the differences in sprouting times between the white oak species and red oak species, the experiment was conducted at two different times. The white oak species ( $Q$. alba, $Q$. prinus, and $Q$. michauxii) were inoculated first, followed by the red oak $(Q . r u$ bra, $Q$. palustris, and $Q$. coccinia) approximately 4 months later. Oak acorns were used for inoculations when a primary root radicle at least $3 \mathrm{~cm}$ long developed but before secondary roots formed, and were placed in a beaker so that the zoospore suspension covered the radicles completely. Three beakers of zoospore suspension were prepared, each containing five sprouted acorns. Additionally, five sprouted acorns were placed in a fourth beaker containing only MES buffer, as a negative control. The beakers were incubated at $20^{\circ} \mathrm{C}$ in the dark. After 1-, 6-, and 24-h periods of exposure, five sprouted acorns were removed, rinsed by dipping into sterile distilled water, and planted individually in $100-\mathrm{cm}^{2}$ pots containing Fafard 52 mix. Controls were removed from the MES buffer after $24 \mathrm{~h}$ and similarly planted. The pots were placed randomly on a bench in the greenhouse and watered by drip irrigation twice per day.

After 4 weeks, the plants were carefully removed from the pots and the soil washed off the roots. The roots were cut at the soil line, dried by blotting on a paper towel, and weighed. The entire root system of each plant was plated on PARPH medium with clarified V8 broth (PARPH+V8) at $20 \mathrm{ml} /$ liter by first surface sterilizing in $70 \%$ ethanol for $10 \mathrm{~s}$, rinsing three times in sterile water, and blotting dry on a sterile paper towel. The plates were sealed and placed in an incubator at $20^{\circ} \mathrm{C}$. After approximately 1 week, the plates were examined and the individual root system recorded as positive for $P$. ramorum infection if a minimum of one colony grew from the roots. Verification for identification of $P$. ramorum was confirmed by visual observation of the characteristically large chlamydospores and semi-papillate sporangia on the agar (58). The experiment was conducted three times for each species, except for Q. rubra, which was only done twice due to lack of acorn availability.

The effects of $P$. ramorum on oak root weight and pathogen exposure time on root infection for each individual species tested were analyzed by analysis of variance (ANOVA) using SAS (version 9.2; SAS Institute). For significant effects, means were compared using Tukey's test $(P=0.05)$. The effect of zoospore concentration on infection for each species was compared by regression analysis using SigmaPlot (version 11.0; SPSS Inc.). The controls, which were not exposed to the pathogen and, thus, had root infection levels of zero, were not included in the analysis. The concentration effect was considered significant at $P \leq 0.05$.

Infection over 5 months. Six seedlings of $Q$. prinus, selected for similar phenology (having two to three leaves at 3 to 4 weeks after acorn germination), were planted in pots of Turface MVP (Profile Products LLC), a calcined, montmorillonite clay substrate medium, and inoculated with a suspension of 500 sporangia/ml (50 $\mathrm{ml} / \mathrm{pot}$ ) of isolate NS-5C. The potted seedlings were incubated overnight and removed from the infested Turface MVP, washed thoroughly to remove any infested mix, and transplanted into fresh Turface MVP. Six seedlings were treated with water as a negative control. All seedlings were grown in the greenhouse at $20 \pm 5^{\circ} \mathrm{C}$ for 5 months; then, percent root infection was estimated from approximately $1201-\mathrm{cm}$ root segments per plant, which were surface sterilized in $5 \%$ bleach (5.25\% sodium hypochlorite) and plated on PARPH. After 1 week at $20^{\circ} \mathrm{C}$, colonies from plated roots were counted. The plated root segments were then removed from the plates, dried at $100^{\circ} \mathrm{C}$, and added to the entire root system, which was dried separately. The experiment was run twice. Total seedling biomass and root biomass were analyzed by the general linear models (GLM) process in SAS and treatment means compared using least significant difference (LSD) to test the treatment differences.

Concentration effect on infection. White oak species ( $Q$. alba and $Q$. prinus) and red oak species ( $Q$. rubra and $Q$. palustris) were collected and treated as described above. Once enough acorns had sprouted and before development of secondary roots on the radicle, zoospores of WSDA-1772 were prepared and counted, as described above. Zoospores were diluted in $0.1 \mathrm{mM}$ MES buffer, $\mathrm{pH} 6.2$, in 500-ml beakers at concentrations of 1, 10, 100, and 1,000 zoospores $/ \mathrm{ml}$. The presence of 1 and 10 zoospores $/ \mathrm{ml}$ was verified by carefully rocking the suspensions after dilution to get an even distribution throughout the solution, removing $1 \mathrm{ml}$ with a pipette, and plating on PARPH+V8 medium (10 plates/ concentration). The plates were sealed and placed in an incubator at $20^{\circ} \mathrm{C}$. After 5 days, the colonies per plate were counted. The sprouted acorns were placed in a beaker so that the zoospore suspension covered the radicles completely. Five sprouted acorns of each species were placed in beakers containing the different 
concentrations of zoospore suspension. Controls were also included, treated in the same manner, except exposed to only MES buffer. The beakers were placed in an incubator at $20^{\circ} \mathrm{C}$ in the dark. After $24 \mathrm{~h}$ of exposure, the sprouted acorns were removed, rinsed by dipping into sterile distilled water, and planted individually in $10-\mathrm{cm}^{2}$ pots containing Fafard $52 \mathrm{mix}$. The pots were placed randomly on a bench in the greenhouse and watered by drip irrigation twice per day.

After 4 weeks, evaluation of seedlings and reisolation of the pathogen was done as described above for the infection timing experiment. Verification for identification of $P$. ramorum was confirmed as described above. Based upon availability of collected acorns that sprouted, the experiment was conducted five times for $Q$. alba and $Q$. prinus, three times for $Q$. palustris, and two times for $Q$. rubra

The effect of zoospore concentration on infection for each species was compared by regression analysis using SigmaPlot (version 11.0; SPSS Inc.). The controls, which were not exposed to the pathogen and, thus, had root infection levels of zero, were not included in the analysis. The concentration effect was considered significant at $P \leq 0.05$.

Inoculum production from roots. Oak seedlings were tested for inoculum production from roots, using an assay developed to quantify $P$. ramorum inoculum in runoff from potted plants in greenhouse experiments (47). Acorns of $Q$. alba, $Q$. prinus, $Q$. palustris, and $Q$. rubra were germinated as described above and planted in 5-by-5-cm plastic pots filled with Turface MVP. Oak seedlings were used once true leaves and secondary roots formed. Because white oak acorns germinate in the fall, three of four assays were run in the fall and the final assay was run in the spring, whereas all four red oak assays were run in the spring. In each trial, Viburnum tinus L. was used as the positive control because cuttings from this plant root readily in Turface MVP at all times of year and are uniform in size when taken from single node/internode stem segments (47). A sporangial suspension of $P$. ramorum $(20 \mathrm{ml}$ of isolate $\mathrm{NS}-5 \mathrm{C}$ at 500 sporangia/ml) was poured into a pot containing an oak seedling or $V$. tinus cutting and held for $24 \mathrm{~h}$; then, the carefully washed plants were transplanted into 5-by-5-cm plastic pots containing clean Turface MVP. The bottom of each pot was first lined with a plastic mesh insert (pore size approximately $0.5 \mathrm{~mm}$ ) to improve drainage. To quantify inoculum in runoff from an inoculated plant, samples were taken on days 1, $4,7,10$, and 16 by adding a sufficient volume of distilled water to each pot so that 20 to $25 \mathrm{ml}$ of runoff could be collected in a plastic centrifuge tube. Runoff was then subsampled using a plastic syringe, where 1-ml aliquots were transferred to three plates of PARPH. The aliquot was spread over the entire plate surface, then incubated at $20^{\circ} \mathrm{C}$. Plates were subsequently examined weekly for 3 weeks and all colonies counted using a dissecting microscope with dark-field illumination (under which colonies of $P$. ramorum are characteristically highly refractive). At the end of the experiment, roots were washed and $601-\mathrm{cm}$ segments were plated on PARPH selective media; remaining roots were surface sterilized in $10 \%$ bleach $(5.25 \%$ sodium hypochlorite) for $60 \mathrm{~s}$ and then an additional $601-\mathrm{cm}$ segments were plated on PARPH. The remainder of the root system was dried at $100^{\circ} \mathrm{C}$. After the root segments had incubated for 1 week at $20^{\circ} \mathrm{C}$, colonies from plated roots were counted to determine percent root infection. The plated roots segments were then removed from the plates, dried at $100^{\circ} \mathrm{C}$, and added to the root system dried above. The dry weight of the entire root system for each plant was recorded. Total inoculum produced over the test period by a plant was divided by dry root weight to derive CFU per dry root weight (dry wt). For oak, lateral roots were weighed separately from the tap root, and lateral root weight was used to calculate CFU per gram of dry wt.

In addition, white oak seedlings were tested for inoculum production over a longer term ( 5 weeks) to determine whether they became infected at a slower rate than $V$. tinus. In two trials, seedlings of $Q$. alba and $Q$. prinus and cuttings of $V$. tinus were inoculated as described above (two plants of each species were inocu- lated with distilled water and served as negative controls) and runoff was sampled weekly for 5 weeks. At the end of the experiment, root segments were plated as described before, and the entire root system was dried at $100^{\circ} \mathrm{C}$ to determine dry wt.

Inoculum in runoff over time was analyzed statistically using the mixed-model analysis of covariance program in SAS to take into account that the same plants were sampled over time. Before analyses, the data set "colonies per pot" was transformed using a logarithmic (base e) transformation, with " 0 " values replaced by " 1 " to retain low counts on the log scale. The transformed variable was analyzed by random coefficient analysis using PROC MIXED. The terms "expt" and "day" were used in the random coefficient analysis, whereas the test variable was considered a fixed effect. Pairwise treatment differences were compared using the LSD at each sampling time. To calculate colonies per gram of dry wt per plant, the amount of inoculum produced during the entire experimental time period was divided by dry wt. This was analyzed by PROC GLM in SAS, and treatment means were compared using LSD. Percent root colonization (calculated from washed root segments) was analyzed by doing an arcsin square root transformation and comparing treatments using GLM and a Dunnett test specifying Viburnum spp. as the positive control. A logistic regression was also run with comparisons among species done using the odds ratio and PROC GLIMMIX.

\section{Results}

Infection timing. The majority of the inoculated radicles developed a root system and a stem. However, $2.4 \%$ of the germinated acorns had a root system but no stem, and $0.9 \%$ had neither a root system nor a stem. It was unclear why no stem appeared on the developed root system but the lack of a root system after germination was attributed to insect damage, based on the presence of insect larvae in some of the acorns. Of those acorns that developed normally, no damping-off of the seedlings was observed on any of the species. Visual observations of the root system did not show any obvious root lesions or sloughing. After plating on the PARPH+V8 medium, all oak species showed some infected roots even when only exposed for $1 \mathrm{~h}$ to the zoospore suspension (Fig. 1). There were no statistical differences between the time of root exposure and percent root infection for $Q$. alba $(P=0.531), Q$. michauxii $(P=0.854), Q$. prinus $(P=0.729), Q$. cocchinia $(P=$ 0.492), $Q$. palustris $(P=0.079)$, and $Q$. rubra (no statistical data because all samples were infected). There was no infection on the controls. The root weights for $Q$. alba, $Q$. michauxii, $Q$. prinus, $Q$. rubra, and $Q$. coccinia were not significantly different $(P$ values $=$ $0.382,0.792,0.625,0.143$, and 0.597 , respectively) among any of the exposure times and, therefore, were combined within each

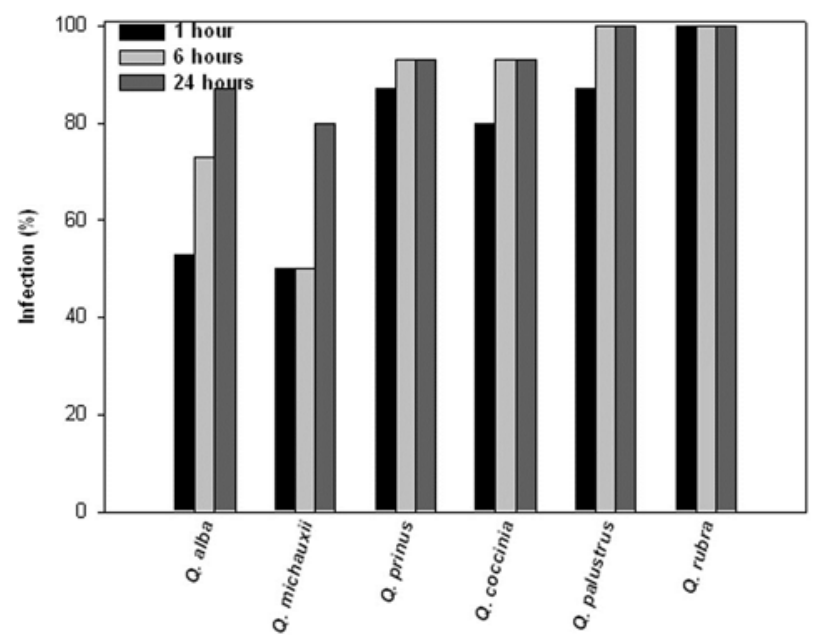

Fig. 1. Percentage of Quercus spp. root systems ( $n=15$ plants/species) infected with Phytophthora ramorum after an initial exposure of 1,6 , or $24 \mathrm{~h}$ to $P$. ramorum zoospores (3,000 zoospores $/ \mathrm{ml}$ ) and growing in the greenhouse for 4 weeks. 
species to compare against the respective noninoculated control (Fig. 2). Root weights of $Q$. palustris were different $(P=0.0066)$ but only significantly so between the control and 1-h exposure. When the infected root treatments were combined, the control root weight was significantly lower than the infected root weight for $Q$. palustris. All other species showed no difference between infected and noninfected root weights.

Infection over 5 months. For seedlings inoculated and allowed to grow for 5 months, $83 \%$ were colonized at the end of the experiment (five of six seedlings for each experiment). Percent colonization was low: 0.6 to $3.2 \%$. There was no difference in total weight or root weight of inoculated seedlings compared with controls.

Concentration effect on infection. As observed in the infection timing experiment above, no damping-off of the resulting oak

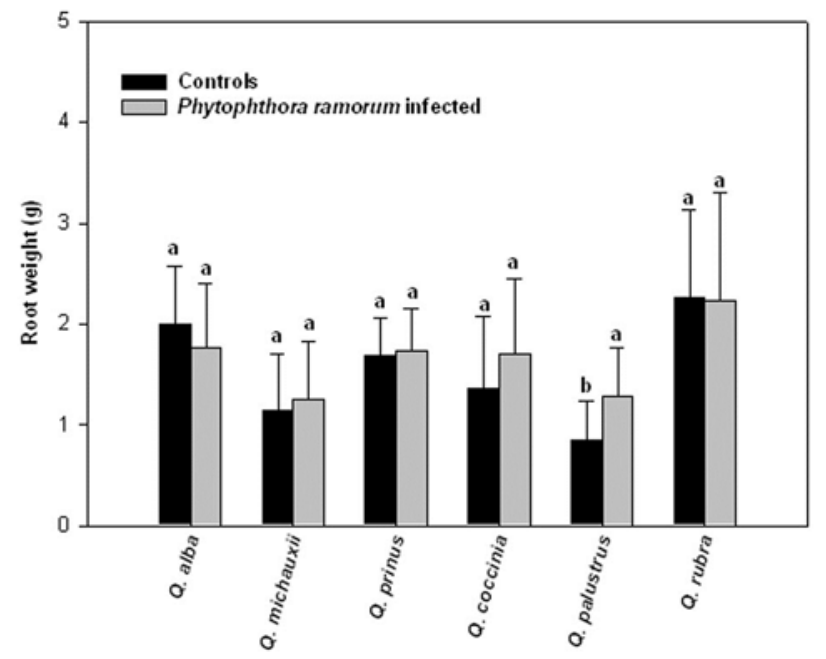

Fig. 2. Fresh root weight of Quercus spp. after 4 weeks of growth of noninfected controls or after the root radicle was exposed to Phytophthora ramorum at 3,000 zoospores $/ \mathrm{ml}$. Each column is the mean of 45 plants, averaged across three exposure periods $(1,6$, and $24 \mathrm{~h})$. Error bars represent standard error of the mean. Points with overlapping error bars are not significantly different at $P \leq 0.05$, according to Tukey's test. seedlings, or obvious root lesions or sloughing, was observed on any of the species tested. The roots of the inoculated plants looked similar to the noninoculated controls, which were suberized and firm. Roots were rated positive for infection when $P$. ramorum was observed growing from the roots after plating on the PARPH+V8 medium. Zoospore concentrations as low as 1 zoospore/ml were adequate to infect some of the roots of all four oak species tested (Fig. 3). For all species (except for Q. rubra), a linear regression that was significant to concentration was determined. Plating on $\mathrm{PARPH}+\mathrm{V} 8$ of the diluted zoospore inoculum to verify concentrations at the lower levels (1 and 10 zoospores $/ \mathrm{ml}$ ) were, on average, less than the targeted 1 and 10 zoospores $/ \mathrm{ml}$, respectively (data not shown).

Inoculum production from roots. When inoculum from runoff was quantified from $V$. tinus, $Q$. alba, and $Q$. prinus every 3 days for 16 days and analyzed using a mixed-model regression analysis of covariance, "host" alone was not significant but day, day-day, day-host, and day-day-host were all significant at $P<0.006$ in type 3 tests of fixed effects. The regression equation for Viburnum spp., differed significantly from those of the oak in both linear and quadratic coefficients. When hosts were compared at each sampling day using a $t$ test, there were no significant differences among hosts on day 1 but inoculum was significantly greater from Viburnum spp. than from oak beginning on day 4; and, on days 7, 10 , and $13, Q$. prinus produced more inoculum than $Q$. alba (Fig. 4A). When inoculum production from roots was totaled for each host and corrected for dry wt (to get CFU/g of dry wt) and analyzed by GLM, "host" was significant at $P<0.0001$ and a $t$ test showed Viburnum spp. producing significantly more inoculum than oak, and $Q$. prinus producing significantly more inoculum than $Q$. alba (Fig. 4B).

When percent root colonization at the end of the experiment was compared using GLM or ANOVA using PROC MIXED, hosts did not differ significantly ( $P=0.089$ and 0.078 , respectively). When a logistic analysis was used to convert percent data into the number of infected or noninfected items (indicated by 0 or 1 , respectively), there was a significant effect for host when oak were compared with Viburnum spp. using an odds ratio test. This showed that a Viburnum sp. was twice as likely to become infected via roots as white oak. A GLIMMIX analysis of the odds ratio for the hosts
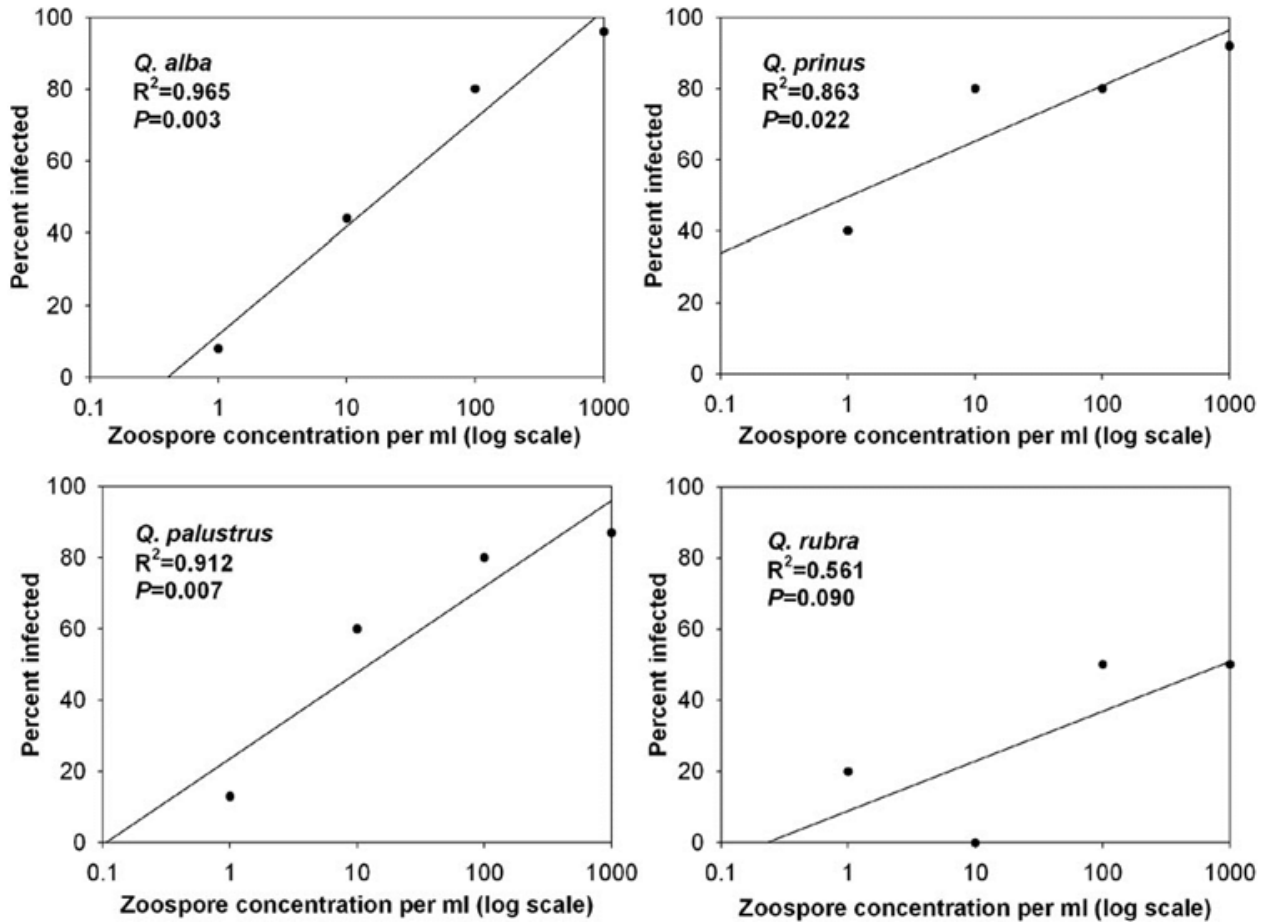

Fig. 3. Effect of Phytophthora ramorum zoospore concentration on the percentage of Quercus spp. root systems infected after an initial exposure time of $24 \mathrm{~h}$ and a 4 -week post-inoculation period. 
showed significant differences among all three hosts using LSD, with Viburnum spp. showing the most infection, $Q$. alba showing intermediate infection, and $Q$. prinus showing the least infection (Fig. 4C). Surface-sterilized roots yielded $0.08 \%$ infection in $Q$. alba and $4.3 \%$ in Q. prinus, compared with $33.1 \%$ in V. tinus.
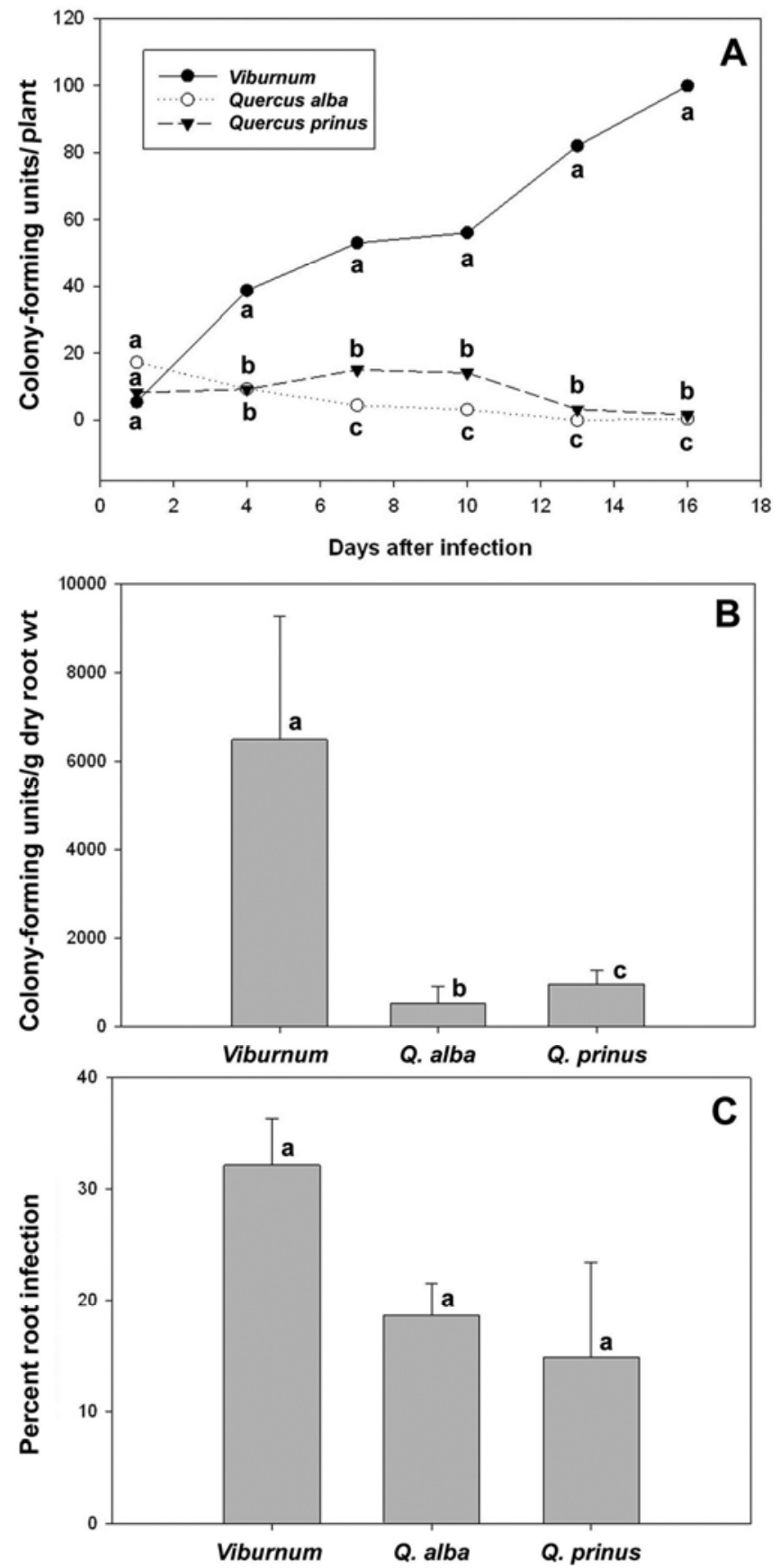

Fig. 4. Inoculum production on and root infection of white oak Quercus alba and $Q$. prinus compared with Viburnum tinus after inoculation of roots with a sporangial suspension of Phytophthora ramorum. A, Inoculum (CFU) collected from runoff per plant every 3 days over a 16-day period. Data at each sampling time were compared using least significant difference and treatments followed by different letters differed significantly. B, Total inoculum collected from runoff from each host and corrected for dry root weight (total $\mathrm{CFU} / \mathrm{g}$ of dry root weight) using measurements of root weight taken at the end of the experiment. Averages of $\mathrm{CFU} / \mathrm{g}$ for each host (averaged over four experiments) include error bars for standard error, and host plants labeled with different letters differed significantly by a general linear models (GLM) analysis with paired $t$ tests. C, Percent root colonization by $P$. ramorum at the end of the experiment ( 16 days). Average percent root colonization for each host includes error bars for standard error, and host plants labeled with different letters differed significantly by a GLM analysis, with a Dunnett test specifying Viburnum as the control treatment.
When inoculum production from Viburnum spp. and red oak $(Q$. rubra and $Q$. palustris) was compared, LSD showed no significant difference among hosts at day 1 but, at every subsequent sampling period, Viburnum spp. differed significantly $(P<0.0001$; Fig. 5A). So little inoculum was produced from red oak that, when total inoculum production was corrected for dry wt, these values could not be compared because the data could not be normalized (Fig. 5B). Percent infection analyzed by GLM showed significant differences among hosts $(P=0.01)$, with Dunnett's $t$ test showing $Q$. palustris having significantly less infection than Viburnum spp. A logistics test showed, in an odds ratio estimate, that a Viburnum sp. was three times more likely to become infected than $Q$. rubra and 37 times more likely to become infected than $Q$. palustris. PROC GLIMMIX with LSD showed each host to differ significantly from the other, with $V$. tinus showing the most infection and $Q$. palustris the least. Surface-sterilized roots yielded $0.12 \%$ infection in $Q$. palustris and $0.57 \%$ in Q. rubra, compared with $13.1 \%$ in V. tinus.

Five-week test of inoculum production by white oak. When inoculum from runoff was quantified from $V$. tinus, $Q$. alba, and $Q$. prinus weekly for 5 weeks and analyzed using a mixed regression model analysis of covariance, only "host" was significant because results were similar at each sampling date. Viburnum spp. produced significantly greater amounts of inoculum than white oak according to LSD analysis for each date $(P<0.0001)$ (Fig.6A). Day, dayday, day-host, and day-day-host were not significant. Total inoculum produced over the course of the experiment corrected for dry wt showed that $V$. tinus produced significantly more inoculum than
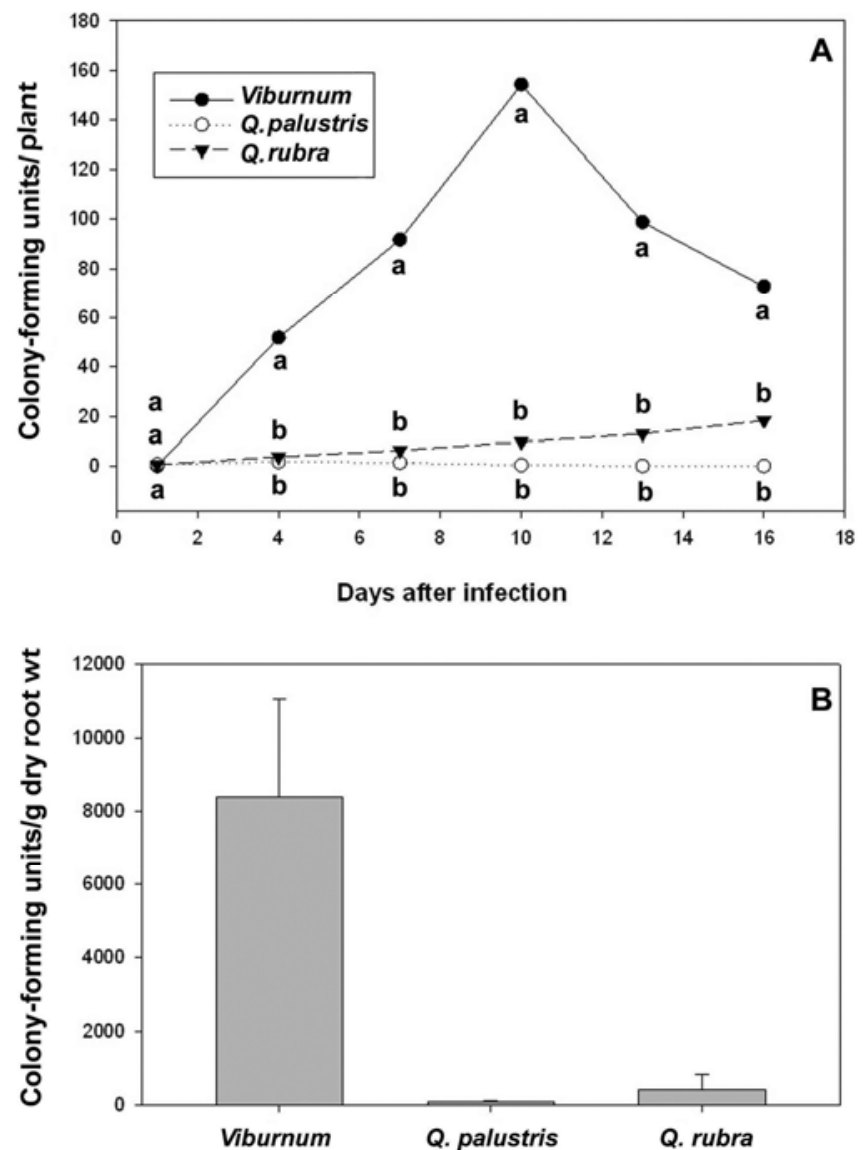

Fig. 5. Inoculum production on and root infection of red oak Quercus palustris and Q. rubra compared with Viburnum tinus after inoculation of roots with a sporangial suspension of Phytophthora ramorum. A, Inoculum (CFU) collected from runoff every 3 days over a 16-day period. Data at each sampling time were compared using least significant difference and treatments followed by different letters differed significantly. B, Total inoculum collected from runoff from each host and corrected for dry root weight (total CFU/g of dry root weight) using measurements of root weight taken at the end of the experiment. Data could not be normalized for statistical analysis. 
the white oak species over 5 weeks, using an LSD test to compare hosts (Fig. 6B). Root infection was difficult to summarize; using GLM, one trial showed $V$. tinus to be significantly more infected than either oak species $(P=0.004)$ and, in the other, hosts did not differ significantly. Surface-sterilized roots yielded $4.2 \%$ infection in $Q$. palustris and $1.3 \%$ in Q rubra, compared with $20.0 \%$ in $V$. tinus.

\section{Discussion}

Germinated oak acorns were used in this study for two reasons. First, the small size of the plants makes it possible to do experiments that would be difficult or impossible with saplings or adult oak. Second, seedlings are an important component of oak ecology. Post-emergence damping-off of tree seedlings caused by Phytophthora spp. can be a problem (7). In this work, although the overwhelming majority of $P$. ramorum-inoculated pre-germinated acorns produced seedlings without damping-off, results from this study showed that sprouted acorns are, nevertheless, susceptible to $P$. ramorum infection after only a short exposure period $(1 \mathrm{~h})$ and even at the lower (less than 10 zoospores $/ \mathrm{ml}$ ) zoospore concentrations. Robin et al. (41) showed similar results of infection without mortality after infecting red oak taproots with $P$. cinnamomi Rands.

Results from this study show that the six selected Quercus spp., native to the eastern United States, are susceptible to root infection by $P$. ramorum zoospores. However, based upon absence of root lesions or root sloughing and because root weights were not different between infected and noninfected roots, even after 5 months, $P$. ramorum does not appear to negatively impact seedling emergence and growth. In fact, root weights of inoculated $Q$. palustris were
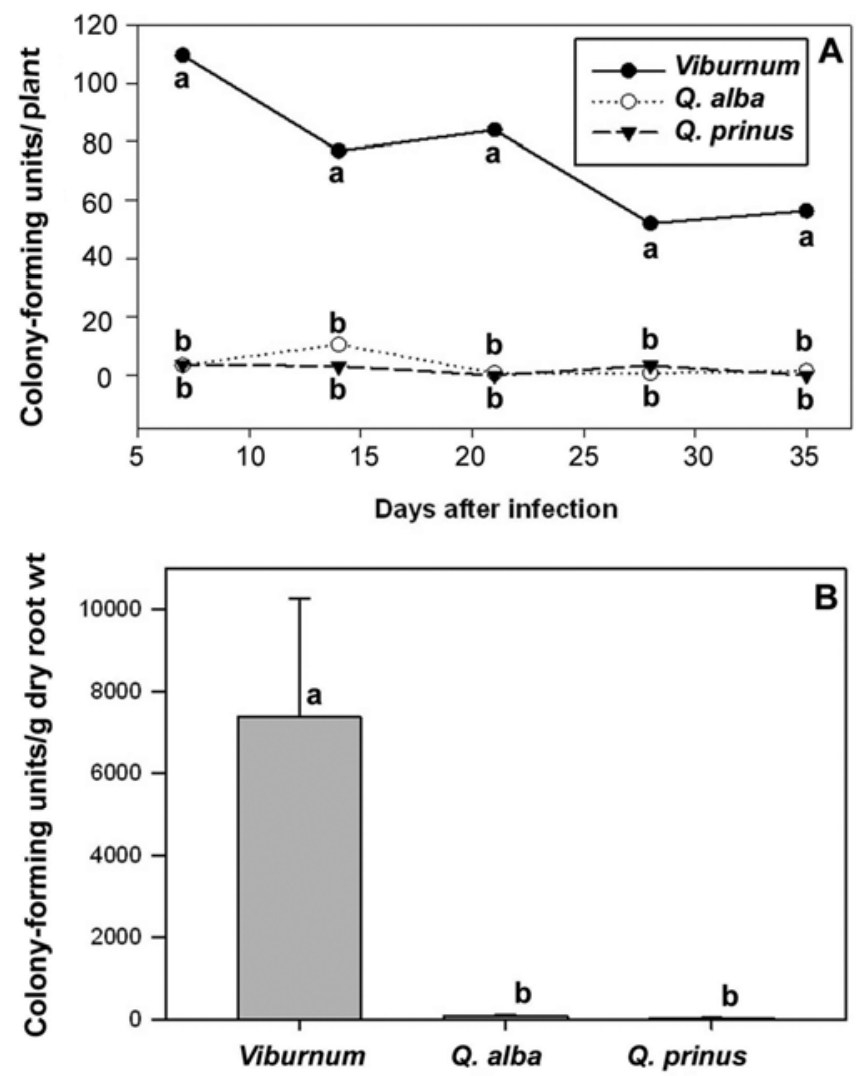

Fig. 6. Inoculum production on and root infection of white oak Quercus alba and $Q$. prinus compared with Viburnum tinus over the course of 5 weeks following infection by Phytophthora ramorum. A, Inoculum (CFU) collected from runoff weekly over a 5-week period. Data at each sampling time were compared using least significant difference and treatments followed by different letters differed significantly. B, Total inoculum collected from runoff from each host and corrected for dry root weight (total CFU/g of dry root weight) using measurements of root weight taken at the end of the experiment. Averages of CFU/g for each host (averaged over four experiments) include error bars for standard error, and host plants labeled with different letters differed significantly by a general linear models analysis with paired $t$ tests. significantly greater than the noninoculated roots at 4 weeks, suggesting that the plant may have compensated for infection by producing more roots. This is in contrast to $P$. quercina and $P$. cactorum, which cause root rot of oak (25), and other Phytophthora root rot species $(1,27,51)$ that showed a decrease in root mass of inoculated plants. Although negative effects on the seedlings were not observed, the fact that root penetration and secondary sporulation on the roots does occur demonstrates the significance of this finding epidemiologically. The lack of observed root lesions on the oak is not unusual for P. ramorum. Fichtner et al. (19) observed asymptomatic infections of rhododendron roots in infested U.K. woodlands, and Parke and Lewis (42) made similar observations in container rhododendron growing in artificial potting medium. The significance of root infection in spread of $P$. ramorum into the landscape may not be in the degree of infection but in its persistence. Even though $P$. cinnamomi removed chestnut, a susceptible host in the family Fagaceae, from most of its southern range decades ago, $P$. cinnamomi is still the most commonly isolated Phytophthora sp. in northern forests soils associated with the roots of oak (4). If $P$. ramorum persists in eastern forests, it may be able to spread to susceptible hosts when they are encountered.

Another significant finding of this study is the production and release of $P$. ramorum propagules from oak roots into soil. Compared with many other hosts of $P$. ramorum, the white oak tested in this study, $Q$. prinus and $Q$. alba, would rank fairly high in inoculum production (46), although not in the same quantity produced by $V$. tinus roots. However, this study clearly shows that these eastern Quercus spp. are not dead-end hosts epidemiologically, releasing sporangia that have the potential to infect new hosts. The role of root infection and inoculum production from roots in the epidemiology of $P$. ramorum is poorly understood but could be significant in both nursery settings and forests. Heungens et al. (23) suggested, on the basis of study of containerized nursery stock, that aerial dispersal of $P$. ramorum is limited to less than $1 \mathrm{~m}$ but spread via runoff can occur over several meters on a non-draining surface, and is a much more likely means of spread among potted plants grown under such conditions. The presence of $P$. ramorum in waterways is also a potential means of spread (53). $P$. alni Brasier \& S.A. Kirk is a hybridized pathogen of alder trees that has spread in waterways in Europe since the early 1990s (8). It attacks the root and collar of alder trees, with a greater risk to trees on slow-moving waterways with warmer water temperatures (50). $P$. ramorum inoculum has been found in streams in California, Washington, and Oregon $(12,40,49)$; however, it is not yet clear if inoculum in streams commonly causes plants to become infected. In Washington, symptomatic plants were found alongside a ditch with water from which $P$. ramorum had been baited (11). The ditch surrounded the perimeter of a nursery that had received infested plants; the presumption was that those plants became infected after immersion in the ditchwater. The source of stream inoculum is unclear; it could include infected leaves and infested soil but could also be released from infected roots, as demonstrated in this study. The role of roots in the disease cycle of this pathogen in wild land settings needs to be further examined. Further studies will need to be conducted to determine the affect of root age on spore production and whether the oak root system can support abundant formation of chlamydospores, which are less likely to detach and be collected in the run-off. Root colonization in these tests was relatively high compared with other plants tested using this assay (46); $Q$. prinus and $Q$. rubra were 2 to 3 times less likely than $V$. tinus to be infected according to an odds ratio test, whereas species of $\mathrm{Ca}$ mellia were 11 to 16 times less likely to become infected $(\mathrm{N}$. Shishkoff, unpublished data).

Infection of the emerging oak radicle by extremely low numbers of $P$. ramorum zoospores demonstrates the infectious ability of $P$. ramorum and the ability to establish in the root system. In this experiment, only the radical was inoculated. However, when the entire root system was plated on the selective medium, it was noted that lateral roots were infected. Because the roots were surface sterilized prior to plating, colony growth demonstrates that the 
roots were invaded and that the pathogen moved within the root system; or more likely because infection sites were not adjacent to the tap root, infective propagules were released in the soil that were able to infect new roots. Results in this study showed that oak roots are capable of supporting sporangia production that can be released and moved in the soil profile by water movement. This is supported by Benson et al. (5), who demonstrated that P. cinnamomi was capable of moving through the soil, spatially infecting new Frasier fir roots.

It is recognized that inoculations in this study were conducted under artificial conditions that may be perceived as giving an advantage to the pathogen and, thereby, resulting in above-normal infection levels. However, we do not feel that this advantage was so great as to discredit the results and, without the presence of specific microbial antagonists, this may not be the case for Phytophthora spp. in general. For example, Bumbieris (9) showed that P. cryptogea was able to colonize pine roots that were already colonized by soil microorganisms and Jönsson (25) found that $P$. quercina and $P$. cactorum caused significant root dieback of $Q$. robur seedlings in nonsterile forest soil. In addition, the oak radicles themselves that were exposed to zoospores were not surface sterilized prior to inoculation and, presumably, contained abundant microorganisms on their surfaces. In any given forest, however, specific antagonists may exist and this may help to explain why $P$. ramorum has not been isolated from roots of Quercus spp. Also, mycorrhizal fungi are commonly found on oak roots in nature (6), although various studies have concluded differently regarding the affect on infection of various host roots by Phytophthora spp. Davis et al. (16) showed little or no difference in response to P. parasitica (synonym $=P$. nicotianae) and $P$. megasperma on citrus and alfalfa seedlings, respectively. However, mycorrhizal avocado seedlings were affected more severely by $P$. cinnamomi then nonmycorrhizal avocado seedlings. Other studies have also demonstrated mycorrhizal colonization of roots to be effective as a mechanical and chemical barrier against Phytophthora spp. (62). P. cinnamomi zoospores encysted and germinated on both nonmycorrhizal and ectomycorrhizal roots of Eucalyptus marginata Donn ex Sm. seedlings but subsequent infection of root tissue was influenced by the type of ectomycorrhizal symbiont and the mycorrhizosphere population associated with the roots (33). This factor was not taken into consideration in this study because it is unlikely that mycorrhizal infection of the expanding embryo occurs until after secondary root formation (2).

Obviously, the behavior of adult trees cannot be predicted from the behavior of seedlings. Further study of the susceptibility of roots of adult Quercus spp. trees and the significance of the propagules produced by these roots in terms of spread and new infections will still need to be done. However, this study does show that P. ramorum can infect the Eastern U.S. Quercus spp., which should be taken into consideration when producing further risk analyses.

\section{Commercial Endorsement Disclaimer}

The use of trade, firm, or corporation names in this article is for the information and convenience of the reader. Such use does not constitute an official endorsement of approval by the USDA Agricultural Research Service, NAL, or BIC of any product or service to the exclusion of others that may be suitable.

\section{Equal Opportunity Statement}

The U.S. Department of Agriculture (USDA) prohibits discrimination in all its programs and activities on the basis of race, color, national origin, age, disability, and where applicable, sex, marital status, familial status, parental status, religion, sexual orientation, genetic information, political beliefs, reprisal, or because all or a part of an individual's income is derived from any public assistance program. (Not all prohibited bases apply to all programs.) Persons with disabilities who require alternative means for communication of program information (Braille, large print, audiotape, etc.) should contact USDA's TARGET Center at (202) 720-2600 (voice and TDD). To file a complaint of discrimination write to USDA, Director, Office of Civil Rights, 1400 Independence Avenue, SW, Washington, DC 20250-9410 or call (800) 795-3272 (voice) or (202) 720-6382 (TDD). USDA is an equal opportunity provider and employer.

\section{Literature Cited}

1. Alva, A. K., Lanyon, L. E., and Leath, K. T. 1985. Influence of fungal-soil water interactions on Phytophthora root rot of alfalfa. Biol. Fertil. Soils 1:91-96.

2. Arnold, B. C., 1960. Mycorrhizal infection of germinating seedlings of Nothofagus solandri var. cliffortioides (Hook f.). Pac. Sci. 14:248-250.

3. Asare-Nyako, A., and Dakwa, J. T. 1974. The disease on roots. Pages 125129 in: Phytophthora Disease of Cocoa. P. H. Gregory, ed. Longman Group, Ltd., London.

4. Balci, Y., Balci, S., Eggers, J., MacDonald, W. L., Juzwik, J., Long, R. P., and Gottschalk, K. W. 2007. Phytophthora spp. associated with forest soils in eastern and north-central U.S. oak ecosystems. Plant Dis. 91:705-710.

5. Benson, D. M., Grand, L. F., Vernia, C. S., and Gottwald, T. R. 2006. Temporal and spatial epidemiology of Phytophthora root rot in Fraser fir plantations. Plant Dis. 90:1171-1180.

6. Bergemann, S. E., and Garbelotto, M. 2006. High diversity of fungi recovered from the roots of mature tanoak (Lithocarpus densiflorus) in northern California. Can. J. Bot. 84:1380-1394.

7. Bowman, K. D., Albano, J. P., and Graham, J. H. 2002. Greenhouse testing of rootstocks for resistance for Phytophthora species in flatwood soils. Proc. Fla. State. Hortic. Soc. 115:10-13.

8. Brasier, C. M., Kirk, S. A., Delcan, J., Cooke, D. E. L., Jung, T., and Man In't Veld, W. A. 2004. Phytophthora alni sp. nov. and its variants: designation of emerging heteroploid hybrid pathogens spreading on Alnus trees. Mycol. Res. 108:1172-1184.

9. Bumbieris, M. 1979. Aspects of the biology of Phytophthora cryptogea. Aust. J. Bot. 27:11-16.

10. Cave, G. L., Randall-Schadel, B., and Redlin, S. C. 2008. Risk Analysis for Phytophthora ramorum Werres, de Cock \& Man in't Veld, Causal Agent of Sudden Oak Death, Ramorum Leaf Blight, and Ramorum Dieback. http:// www.aphis.usda.gov/plant_health/plant_pest_info/pram/downloads/pdf_files/ pra-cphst-08.pdf

11. Chastagner, G., Coats, K., and Omdal, D. 2011. Mystery on the Sammamish: what are the sources of Phytophthora ramorum infesting this Washington State waterway? (Abstr.) Phytopathology 101:S32.

12. Chastagner, G., Oak, S., Omdal, D., Ramsey-Kroll, A., Coats, K., Valachovic, Y., Lee, C., Hwang, J., Jeffers, S., and Elliott, M. 2010. Spread of $P$. ramorum from nurseries into watersheds-implications for pathogen establishment in new areas. Pages 22-26 in: Proc. Sudden Oak Death Third Sci. Symp. S. J. Frankel, J. T. Kliejunas, and K. M. Palmieri, tech. coords. Gen. Tech. Rep. PSW-GTR-229, Pac. Southwest Res. Stn. For. Serv. U.S. Dep. Agric. Albany, CA.

13. Coffey, M. D. 1991. Strategies for the integrated control of soilborne Phytophthora species. Pages 411-432 in: Phytophthora. J. A. Lucas, R. C. Shattock, D. S. Shaw, and L. R. Cooke, eds. University Press, Cambridge, Great Britain.

14. Davidson, J. M., Rizzo, D. M., Garbelotto, M., Tjosvold, S., and Slaughter, G. W. 2002. Phytophthora ramorum and sudden oak death in California: II. Transmission and survival. U. S. Dep. Agric. For. Serv. Gen. Tech. Rep. PSW-GTR-184.

15. Davidson, J. M., Wickland, A. C., Patterson, H. A., Falk, K. R., and Rizzo, D. M. 2005. Transmission of Phytophthora ramorum in mixed-evergreen forest in California. Phytopathology 95:587-596.

16. Davis, R. M., Menge, J. A., and Zentmyer, G. A. 1978. Influence of vesicular-arbuscular mycorrhizae on Phytophthora root rot of three crop plants. Phytopathology 68:1614-1617.

17. Erwin, D. C., and Ribeiro, O. K. 1996. Phytophthora Diseases Worldwide. American Phytopathological Society, St. Paul, MN.

18. Fichtner, E. J.., Lynch, S. C., and Rizzo, D. M. 2009. Survival, dispersal, and soil-mediated suppression of Phytophthora ramorum in a California redwood-tanoak forest. Phytopathology 99:608-619.

19. Fichtner, E. J., Rizzo, D. M., Kirk, S. A., and Weber, J. 2011. Root infections may challenge management of invasive Phytophthora spp. in U.K. woodlands. Plant Dis. 95:13-18.

20. Graham, J. H., Timmer, L. W., Drouillard, D. L., and Peever, T. L. 1998 Characterization of Phytophthora spp. causing outbreaks of citrus brown rot in Florida. Phytopathology 88:724-729.

21. Gregory, P. H., Griffin, M. J., Maddison, A. C., and Ward, M. R. 1984. Cocoa black pod: a reinterpretation. Cocoa Grow. Bull. 35:5-22.

22. Grünwald, N. J., Goss, E. M., Ivors, K., Garbelotto, M., Martin, F. N., Prospero, S., Hansen, E., Bonants, P. J. M., Hamelin, R. C., Chastagner, G., Werres, S., Rizzo, D. M., Abad, G., Beales, P., Bilodeau, G. J., Blomquist, C. L., Brasier, C., Brière, S. C., Chandelier, A., Davidson, J. M., Denman, S., Elliott, M., Frankel, S. J., Goheen, E. M., de Gruyter, H., Heungens, K., James, D., Kanaskie, A., McWilliams, M. G., Man in 't Veld, W., Moralejo, E., Osterbauer, N. K., Palm, M. E., Parke, J. L., Perez Sierra, A. M., Shamoun, S. F., Shishkoff, N., Tooley, P. W., Vettraino, A. M., Webber, J., and Widmer, T. L. 2009. Standardizing the nomenclature for clonal lineages of the sudden oak death pathogen, Phytophthora ramorum. Phytopathology 99:792-795.

23. Heungens, K., De Dobbelaere, I., Gehesquiere, B., Vercauteren, A., and Maes, M. 2010. Within-field spread of Phytophthora ramorum on rhododendron in nursery settings. Pages $72-75$ in: Proc. Sudden Oak Death 
Third Sci. Symp. S. J. Frankel, J. T. Kliejunas, and K. M. Palmieri, tech. coords. Gen. Tech. Rep. PSW-GTR-229, Pac. Southwest Res. Stn. For. Serv. U.S. Dep. Agric. Albany, CA.

24. Jeffers, S. N., Hwang, J., Wamishe, Y. A., and Oak, S. W., 2010. Detection of Phytophthora ramorum at retail nurseries in the Southeastern United States. Pages 69-71 in: Proc. Sudden Oak Death Third Sci. Symp. S. J. Frankel, J. T. Kliejunas, and K. M. Palmieri, tech. coords. Gen. Tech. Rep. PSW-GTR-229, Pac. Southwest Res. Stn. For. Serv. U.S. Dep. Agric. Albany, CA.

25. Jönsson, U. 2004. Phytophthora species and oak decline: Can a weak competitor cause significant root damage in nonsterilized acidic forest soil? New Phytol. 162:211-222.

26. Jules, E. S., Kauffman, M. J., Ritts, W. D., and Carroll, A. L. 2002. Spread of an invasive pathogen over a variable landscape: a nonnative root rot on Port Orford cedar. Ecology 83:3167-3181.

27. Kellam, M. K., and Coffey, M. D. 1985. Quantitative comparison of the resistance to Phytophthora root rot in three avocado rootstocks. Phytopathology 75:230-234.

28. Kelly, M., Guo, Q., Liu, D., and Shaari, D. 2007. Modeling the risk for a new invasive forest disease in the United States: an evaluation of five environmental niche models. Comput. Environ. Urban 31:689-710.

29. Koch, F. H., and Smith, W. D. 2008. Mapping sudden oak death risk nationally using host, climate, and pathways data. Pages 279-287 in: Proc. Sudden Oak Death Third Sci. Symp. S. J. Frankel, J. T. Kliejunas, and K. M. Palmieri, tech. coords. Gen. Tech. Rep. PSW-GTR-214, Pac. Southwest Res. Stn. For. Serv. U. S. Dep. Agric. Albany, CA.

30. Kroon, L. P. N. M., Verstappen, E. C. P., Kox, L. F. F., Flier, W. G., and Bonants, P. J. M. 2004. A rapid diagnostic test to distinguish between American and European populations of Phytophthora ramorum. Phytopathology 94:613-620.

31. Linderman, R. G., and Davis, E. A. 2007. Comparative host susceptibility and sporulation potential of Phytophthora ramorum on species, cultivars, and hybrids of camellia. Plant Health Progress. Online publication. doi:10.1094/PHP-2007-0822-02-RS

32. Madden, L. V., Wilson, L. L., Yang, X., and Ellis, M. A. 1992. Splash dispersal of Colletotrichum acutatum and Phytophthora cactorum by shortduration simulated rains. Plant Pathol. 41:427-436.

33. Malajczuk, N. 1988. Interaction between Phytophthora cinnamomi zoospores and micro-organisms on non-mycorrhizal and ectomycorrhizal roots of Eucalyptus marginata. Trans. Br. Mycol. Soc. 90:375-382.

34. Mitchell, D. J., Kannwischer-Mitchell, M. E., and Zentmyer, G. A. 1986. Isolating, identifying, and producing inoculum of Phytophthora spp. Pages 63-66 in: Methods for Evaluating Pesticides for Control of Plant Pathogens. Hickey, K. D., ed. American Phytopathological Society, St. Paul, MN.

35. Moser, W. K., Hansen, M., McWilliams, W., and Sheffield, R. 2006. Oak composition and structure in the eastern United States. Pages 49-61 in: Proc. Fire Eastern Oak Forests: Delivering Science to Land Managers Conf. M. B. Dickinson, ed. Gen. Tech. Rep. NRSP-1. U.S. Dep. Agric. For. Serv. North. Res. Stn. Newtown Square, PA

36. Okaisabor, E. K. 1974. Phytophthora pod rot infections from the soil. Pages 161-168 in: Phytophthora Disease of Cocoa. P. H. Gregory, ed. Longman Group, Ltd., London.

37. Opoku, I. Y., Akrofi, A. Y., and Appiah, A. A. 2002. Shade trees are alternative hosts of the cocoa pathogen Phytophthora megakarya. Crop Prot. 21:629-634.

38. Parke, J. L., Bienapfl, J., Oh, E., Rizzo, D., Hansen, E., Buckles, G., Lee, C., and Valachovic, Y. 2006. Natural infection of tanoak seedling roots by Phytophthora ramorum. (Abstr.) Phytopathology 96:S90.

39. Parke, J. L., and Lewis, C. 2007. Root and stem infection of rhododendron from potting medium infested with Phytophthora ramorum. Plant Dis. 91:1265-1270.

40. Rizzo, D. M., Garbelotto, M., and Hansen, E. M. 2005. Phytophthora ramorum: integrative research and management of an emerging pathogen in California and Oregon forests. Annu. Rev. Phytopathol. 43:309-335.

41. Robin, C., Desprez-Loustau, M. L., Capron, G., and Delatour, C. 1998. First record of Phytophthora cinnamomi on cork and holm oaks in France and evidence of pathogenicity. Ann. Sci. For. 55:869-883.

42. Shishkoff, N. 2006. Susceptibility of camellia to Phytophthora ramorum the "sudden oak death" organism. Plant Health Progress. Online publication. doi:10.1094/PHP-2006-03S-01-RS

43. Shishkoff, N. 2007. Persistence of Phytophthora ramorum in soil mix and roots of nursery ornamentals. Plant Dis. 91:1245-1249.

44. Shishkoff, N. 2007. Susceptibility of some Lilac cultivars and other members of the Oleaceae to Phytophthora ramorum. Plant Health Progress. Online publication. doi:10.1094/PHP-2007-1101-02-RS

45. Shishkoff, N. 2009. Propagule production by Phytophthora ramorum on lilac (Syringa vulgaris) leaf tissue left on the surface of potting mix in nursery pots. Plant Dis. 93:475-480.

46. Shishkoff, N. 2011. Risk analysis of native and ornamental plants for root infection and inoculum production from roots by Phytophthora ramorum. (Abstr.) Phytopathology 101:S166.

47. Shishkoff, N. 2011. A test system to quantify inoculum in runoff from Phytophthora ramorum-infected plant roots. Phytopathology 101:14571464. doi:10.1094/PHYTO-09-10-0260

48. Spaulding, H. L., and Rieske, L. K. A glimpse at future forests: predicting the effects of Phytophthora ramorum on oak forests of southern Appalachia. Biol. Invas. In press.

49. Sutton, W., Hansen, E. M., Reeser, P. W., and Kanaskie, A. 2009. Stream monitoring for detection of Phytophthora ramorum in Oregon tanoak forests. Plant Dis. 93:1182-1186.

50. Thoirain, B., Husson, C., and Marçais, B. 2007. Risk factors for the Phytophthora-induced decline of alder in northeastern France. Phytopathology 97:99-105.

51. Timmer, L. W., Agostini, J. P., Graham, J. H., and Castle, W. S. 1991. Relationship of citrus rootstock to Phytophthora root rot and populations of Phy tophthora parasitica. Proc. Fla. State Hortic. Soc. 104:173-178.

52. Timmer, L. W., Sandler, H. A., Graham, J. H., Zitko, S. E. 1988. Sampling citrus orchards in Florida to estimate populations of Phytophthora parasitica. Phytopathology 78:940-944.

53. Tjosvold, S., Chambers, D., and Fichtner, E. 2010. Importance of rainfall and sprinkler irrigation in supporting sporulation, spread of inoculum in runoffwater, and new infections of Phytophthora ramorum under field conditions. Pages 76-77 in: Proc. Sudden Oak Death Third Sci. Symp. S. J. Frankel, J. T. Kliejunas, and K. M. Palmieri, tech. coords. Gen. Tech. Rep. PSW-GTR-229, Pac. Southwest Res. Stn. For. Serv. U. S. Dep. Agric. Albany, CA.

54. Tooley, P. W., and Browning, M. 2009. Susceptibility to Phytophthora ramorum and inoculum production potential of some common Eastern forest understory plant species. Plant Dis. 93:249-256.

55. Tooley, P. W., and Browning, M. 2010. Factors affecting onset of sporulation in Phytophthora ramorum. Pages 373-374 in: Proc. Sudden Oak Death Third Sci. Symp. S. J. Frankel, J. T. Kliejunas, and K. M. Palmieri, tech. coords. Gen. Tech. Rep. PSW-GTR-229, Pac. Southwest Res. Stn. For Serv. U. S. Dep. Agric. Albany, CA.

56. Tooley, P. W., and Kyde, C. 2007. Susceptibility of some eastern forest species to Phytophthora ramorum. Plant Dis. 91:435-438

57. United States Department of Agriculture, Animal and Plant Health and Inspection Service, (Current) List of Regulated Hosts and Plants Proven or Associated with Phytophthora ramorum. http://www.aphis.usda.gov/ plant_health/plant_pest_info/pram/downloads/pdf_files/usdaprlist.pdf

58. Werres, S., Marwitz, R., Man in 't Veld, W. A., de Cock, A. W. A. M., Bonants, P. J. M., de Weerdt, M., Themann, K., Ilieva, E., and Baayen, R. P. 2001. Phytophthora ramorum sp. nov., a new pathogen on Rhododendron and Viburnum. Mycol. Res. 105:1155-1165.

59. Widmer, T. L. 2009. Infective potential of sporangia and zoospores of Phytophthora ramorum. Plant Dis. 93:30-35.

60. Widmer, T. L., and Dodge, S. C. 2009. Susceptibility of sprouted oak acorns to Phytophthora ramorum zoospores. (Abstr.) Phytopathology 99:S205.

61. Widmer, T. L., Shishkoff, N., and Dodge, S. 2010. Root susceptibility and inoculum production from roots of eastern oak species to Phytophthora ramorum. (Abstr.) Phytopathology 100:S136.

62. Zak, B. 1964. Role of mycorrhizae in root diseases. Annu. Rev. Phytopathol. 2:377-392. 